\title{
PENAMBAHAN SEPERTIGA HUKUMAN BAGI PELAKU TINDAK PIDANA PERDAGANGAN ORANG PERSPEKTIF HUKUM PIDANA ISLAM
}

\author{
\begin{tabular}{l|l} 
Vera Chatuningtias Safitri & Perumahan Bluru Permai Blok BJ-26
\end{tabular} \\ pheiianarsiz@yahoo.com $\mid$ Sidoarjo
}

\begin{abstract}
This article highlights the $1 / 3$ additional punishment to perpetrator of the trafficking crime. It is a criminal stipulation as mentioned in Criminal Code Article 7, paragraph (1) added to the 1/3 aggravated punishment, because it contains trafficking and heavy maltreatment (serious injury), severe mental disorder, infectious disease, other life-threatening, pregnancy, or impaired and a loss of reproductive function of the victim. The perpetrator of which is imprisoned for a minimum 4 years and maximum 20 years with the criminal fine of at least Rp. $160,000,000.00$ and at most Rp. $800,000,000.00$. While in figh jinayah, the $1 / 3$ additional punishment included in the theory of 'uqûbah albadaliyyah al-takmîliyyah (substitute and complement punishment). Criminalization of 'uqûbâh al-badaliyyah al-takmîlliyyah is an additional punishment that follows the principal penalty after the issuance of the verdict of the judge. The penalties included in this jarimah are physical punishment and diyat kamilah.
\end{abstract}

Keywords: Additional penalty, trafficking, Islamic Criminal Law.

Abstrak: Penambahan 1/3 hukuman bagi pelaku tindak pidana perdagangan orang adalah penetapan pidana dalam KUHP Pasal 7 ayat (1) ditambahkan dengan diperberat 1/3 hukuman, karena mengandung unsur trafficking dan ditambah melakukan penganiayaan berat, gangguan jiwa berat, penyakit menular lainnya yang membahayakan jiwanya, kehamilan, atau terganggu dan hilangnya fungsi reproduksi korban. Bentuk hukumannya adalah pidana penjara paling singkat 4 tahun dan paling lama 20 tahun disertai pidana denda paling sedikit Rp. 160.000.000,00 dan paling banyak Rp. 800.000.000,00. Sedangkan dalam fiqh jinâyah, penambahan 1/3 hukuman termasuk dalam teori al-'uqûbah al-badaliyyah al-takmîliyyah (hukuman pengganti dan pelengkap). Pemidanaan al'uqûbah al-badaliyyah al-takmîliyyah merupakan hukuman tambahan yang mengikuti hukuman pokok setelah dikeluarkannya putusan dari hakim. Hukuman yang termasuk dalam jarîmah ini adalah hukuman badan ditambah hukuman diyah kâmilah.

Kata Kunci: Penambahan, hukuman, perdagangan orang, hukum pidana Islam. 


\section{Pendahuluan}

Dewasa ini semakin marak eksploitasi manusia untuk dijual atau biasa disebut dengan human trafficking, terutama pada wanita untuk perzinaan atau dipekerjakan tanpa upah dan lainnya, ada juga pada bayi yang baru dilahirkan untuk tujuan adopsi yang tentunya ini semua tidak sesuai dengan syariah dan 'urf (norma-norma yang berlaku dalam masyarakat), kemudian bila ditinjau ulang ternyata manusia-manusia tersebut berstatus al-hurriyah (merdeka).

Perbudakan manusia telah berjalan berabad-abad lamanya, tetapi para ahli sejarah tidak dapat menentukan kapan permulaan perbudakan itu dimulai. Sebagian ahli sejarah berpendapat, bahwa perbudakan itu dimulai bersamaan dengan perkembangan manusia, karena sebagian manusia memerlukan bantuan tenaga dari sebagian manusia lainnya. Karena sebagian manusia merasa mempunyai kekuatan, maka lahirlah keinginan menguasai orang lain dan terjadilah perbudakan manusia atas manusia dan perdagangan orang (trafficking). ${ }^{1}$ Dalam kasus perdagangan orang, ada dua jenis penggolongan orang yaitu al-hurriyah (orang merdeka) dan 'abd atau amah (orang tidak merdeka/budak).

Disebutkan dalam sebuah hadis qudsî Allah swt mengancam keras orang yang menjual manusia dengan ancaman permusuhan di hari Kiamat. Imam al-Bukhâri meriwayatkan dari hadis Abu Hurairah yang menyatakan:

Telah menceritakan kepada saya Yusuf bin Muhammad berkata, telah menceritakan kepada saya Yahya bin Sulaim dari Isma'il bin Umayyah dari Sa'id bin Abi Sa'id dari Abu Hurairah ra dari Nabi saw bersabda: "Allah Ta'ala berfirman: Ada tiga jenis orang yag aku berperang melawan mereka pada hari kiyamat, seseorang yang bersumpah atas namaku lalu mengingkarinya, seseorang yang berjualan orang merdeka lalu memakan (uang dari) harganya dan seseorang yang memperkerjakan pekerja kemudian pekerja itu menyelesaikan pekerjaannya namun tidak dibayar upahnya. ${ }^{2}$

Disebutkan juga dalam hadis Imam al-Bukhâri yang menyatakan: Telah menceritakan kepada kami Qutaibah bin Sa'id dari Malik dari Ibnu Syihab dari Abu Bakar bin 'Abdurrahman bin Al Harits

\footnotetext{
1 Nova Farida, "Perdagangan Manusia dalam Hukum HAM dan Perspektif Islam", http://novafarid.blogspot.com/2012/12/perdagangan-manusia-dalam-hukum-ham-dan.html, diakses pada tanggal 24 bulan Desember tahun 2012.

2 Software Kitab Hadis 9 Imam, Kitab Sahih Imam Al-Bukhâri, CD Hadis No. 2109.
} 
bin Hisyam dari Abu Mas'ud Al-Anshariy ra bahwa Rasulullah saw telah melarang uang hasil jual beli anjing, mahar seorang pezina dan upah bayaran dukun. ${ }^{3}$

Dalam masalah ini ulama bersepakat atas haramnya menjual orang yang merdeka (bay' al-hurr), dan setiap akad yang mengarah ke sana, maka akadnya dianggap tidak sah dan pelakunya berdosa. Perbudakan, dalam arti zaman jahiliyah, disepakati ulama untuk diharamkan. Hal ini tidak berarti perbudakan kemudian lenyap. Perbudakan era jahiliyah kini menjelma dalam bentuk perdagangan orang untuk kepentingan bisnis prostitusi yang dikelola sangat rapi oleh jaringan mafia internasional. Sebagaimana perbudakan berbau seks yang terjadi pada masa nabi dilarang, yang disebutkan dalam Q.S. An-Nûr: 33 yang berbunyi:

Dan orang-orang yang tidak mampu kawin hendaklah menjaga kesucian (diri)nya, sehingga Allah memampukan mereka dengan karunia-Nya, dan budak-budak yang kamu miliki yang menginginkan perjanjian, hendaklah kamu buat perjanjian dengan mereka. Jika kamu mengetahui ada kebaikan pada mereka, dan berikanlah kepada mereka sebagian dari harta Allah yang dikaruniakan-Nya kepadamu. Dan janganlah kamu paksa budak-budak wanitamu untuk melakukan pelacuran, sedang mereka sendiri mengingini kesucian, karena kamu hendak mencari keuntungan duniawi. Dan Barangsiapa yang memaksa mereka, maka sesungguhnya Allah adalah Maha Pengampun lagi Maha Penyayang (kepada mereka) sesudah mereka dipaksa itu. (An-Nûr:33) ${ }^{4}$

Dengan memperhatikan ayat tersebut, trafficking atau perdagangan orangharus diharamkan, dan semua yang terlibat didalamnya berdosa. Pengharaman trafficking tentu bukan tanpa alasan, akan tetapi pengharaman saja belumlah cukup. Bagi pelaku yang melakukan trafficking juga harus diberi sanksi yang dapat mencegah terulanginya perbuatan ini. Hukuman yang diberikan adalah sebagai bentuk pertanggungjawaban pidana oleh pelaku, sebab disamping dapat dikategorikan sebagai kejahatan kemanusiaan karena merampas dan menodai hak-hak dasar manusia, juga mengancam dan merusak tatanan nilai yang dibangun ajaran agama seperti keadilan, kesetaraan,

\footnotetext{
3 lbid., No. 2121.

4 Departemen Agama RI, Al-Qur'an dan Terjemahannya (Jakarta: Yayasan Penyelenggara Penterjemahan, 1971), 549.
} 
kemaslahatan. Nilai-nilai yang sangat penting dan menjadi dasar pijakan dalam upaya membangun hubungan kemanusiaan yang ideal.

Di dalam fiqh jinâyah, hukuman dapat dibagi menjadi beberapa golongan menurut segi tinjauannya yaitu berdasarkan pertalian satu hukuman dengan lainnya yang meliputi hukuman pokok (al-'uqûbah alashliyyah), hukuman pengganti (al-'uqûbah al-badaliyyah), hukuman tambahan (al-'uqûbâh al-tab'iyyah) dan hukuman pelengkap (al-'uqûbâh al-takmîliyyah). Hukuman berdasarkan tempat dilakukannya yaitu meliputi hukuman badan, hukuman jiwa dan hukuman harta. Selain itu, terdapat juga hukuman berdasarkan tindak pidana yang diancamkan meliputi hukuman hudûd, qishâsh, diyat dan ta'zîr. ${ }^{5}$ Sedangkan teori gabungan hukuman dalam fiqh jinayah yaitu teori saling melengkapi (nazhariyyah al-tadâkhul) dan teori penyerapan (nazhariyyah al-jabb). ${ }^{6}$

Dalam teori-teori ini yang akan digunakan penambahan $1 / 3$ hukuman adalah teori saling melengkapi (nazhariyyah al-tadâkhul). Teori saling melengkapi (nazhariyyah al-tadâkhul) terjadi ketika terdapat gabungan perbuatan yang hukumannya saling melengkapi. Sehingga semua perbuatan hanya dijatuhi satu hukuman. ${ }^{7}$ Teori ini memiliki pertimbangan yaitu beberapa perbuatan dianggap satu macam selama obyeknya adalah satu seperti dalam tindak pidana dalam pasal 7 ayat (1), pelaku melakukan tindak pidana trafficking sekaligus penganiayaan yang mengakibatkan luka berat. ${ }^{8}$

Di dalam beberapa pengelompokan macam-macam hukuman tersebut, terdapat beberapa sistem hukuman yang dapat dijadikan pijakan untuk menganalisis penambahan $1 / 3$ hukuman dalam pasal 7 ayat (1) Undang-Undang No 21 Tahun 2007 yaitu sistem hukuman pengganti dan pelengkap (al-'uqûbâh al-badaliyyah al-takmîliyyah). Sebagai pisau analisis dalam menggali hukum, maka trafficking dalam pasal 7 ayat (1) masuk dalam kategori jarîmah penganiayaan yang disengaja yang mengakibatkan cacat fisik, cacat mental, hamil serta penyakit menular lainnya sehingga sistem hukumannya dapat dikenakan qishâsh. Qishâsh artinya pembalasan, yaitu pembalasan setimpal terhadap orang yang melukai. Bagi pelaku dalam Pasal 7 ayat (1) berhak

\footnotetext{
${ }^{5}$ Ahmad Wardi Muslich, Pengantar dan Asas Hukum Pidana Islam: Fikih Jinayah (Jakarta: Sinar Grafika, 2006), 143-144.

${ }^{6}$ Ibid., 168.

7 lbid.

${ }^{8}$ Ahmad Hanafi, Asas-asas Hukum Pidana Islam (Jakarta: Bulan Bintang, 1990), 331.
} 
mendapat perlakuan seperti yang telah dilakukannya atas orang lain. Apabila hukuman qishâsh (al-'uqûbâh al-ashliyyah) tidak dapat dilaksanakan karena alasan yang sah, maka dapat dikenakan hukuman diyat (denda) sebagai pengganti hukuman qishâsh.

Setelah disahkannya Undang-Undang Nomor 21 Tahun 2007 tentang Pemberantasan Tindak Pidana Perdagangan Orang, pada 19 April 2007 yang merupakan peraturan yang khusus yang mengatur tentang tindak pidana perdagangan orang, sehingga dapat menjadi sarana bagi penegakan hukum, khususnya terhadap penanganan perdagangan orang. Adapun perlindungan korban belum mendapat perhatian, hal ini terlihat dari masih sedikitnya aturan dalam peraturan perundangundangan mengenai hak-hak korban. Keberpihakan hukum terhadap korban yang terkesan timpang jika dibandingkan dengan tersangka (terdakwa) dibandingkan kepada korban. Dalam beberapa kasus kejahatan, seringkali wujud perlindungan hukum yang diberikan kepada korban termasuk korban perdagangan orang hanya terbatas pada aspek materiil saja, yaitu diberi hak untuk menuntut ganti kerugian. Harapannya setelah ganti kerugian diberikan penderitaan yang dihadapi korban akan selesai. Padahal akibat yang diderita korban sangat kompleks, tidak hanya kerugian materiil saja tetapi secara fisik dan psikis. ${ }^{9}$

Meskipun sanksi pidana trafficking sangat jelas yaitu penjara 3-15 tahun dan denda Rp. 120 - 600 juta rupiah (Pasal 2-6), namun angka trafficking tidak menunjukkan penurunan. Hal yang demikian ini, sangatlah memprihatinkan. Di dalam pasal 7 ayat (1) disebutkan bahwa:

Jika tindak pidana sebagaimana dimaksud dalam Pasal 2 ayat (2),

Pasal 3, Pasal 4, Pasal 5, dan Pasal 6 mengakibatkan korban menderita luka berat, gangguan jiwa berat, penyakit menular lainnya yang membahayakan jiwanya, kehamilan, atau terganggu atau hilangnya fungsi reproduksinya, maka ancaman pidananya ditambah 1/3 (sepertiga) dari ancaman pidana dalam Pasal 2 ayat (2), Pasal 3, Pasal 4, Pasal 5, danPasal 6.

Penambahan $1 / 3$ hukuman terjadi dikarenakan adanya akibat yang ditimbulkan dari perbuatan pidana tersebut. Contoh kasus di Tulungagung. Di dalam putusan No. 518/ Pid.B/ 2009/ PN. Ta, Pengadilan Negeri Tulungagung telah menjatuhkan hukuman 15

\footnotetext{
${ }^{9}$ Farhana, Aspek Hukum Perdagangan Orang di Indonesia (Jakarta: Sinar Grafika, 2012),19-20.
} 
tahun penjara kepada terdakwa karena terdakwa bukan hanya memperdagangkan dan menyetubuhi, tetapi juga melakukan kekerasan fisik kepada korban. Sehingga terdakwa dikenakan hukuman penjara selama 15 tahun dan denda sebesar Rp. 120.000.000 dengan ketentuan apabila tidak dibayar harus diganti dengan hukuman kurungan selama 12 bulan. ${ }^{10}$

Di dalam hukum pidana terdapat teori tentang hukuman yang meliputi teori gabungan perbuatan dalam hukum positif yaitu teori berganda, teori penyerapan dan teori campuran. Sedangkan teori gabungan perbuatan dalam KUHP meliputi teori penyerapan biasa, teori penyerapan keras, teori berganda yang dikurangi dan teori berganda biasa. Dalam hal gabungan atau perbarengan perbuatan (concursus realis) terdapat sistem hukuman yang berkaitan dengan penambahan $1 / 3$ hukuman yaitu salah satunya menggunakan sistem absorpsi dipertajam (verscherpte absorptiestelsel) yang dipertajam. Sistem ini ancaman hukumannya adalah dijatuhi satu pidana saja dan maksimum pidana yang dijatuhkan adalah jumlah maksimum pidana yang diancamkan terhadap tindak pidana itu, namun masih harus ditambah $1 / 3$ kali maksimum hukuman terberat tetapi tidak boleh lebih dari maksimum pidana yang terberat. ${ }^{11}$ Sistem hukuman juga telah disebutkan dalam Pasal 10 KUHP yang terdiri dari pidana pokok dan pidana tambahan. Pidana pokok terdiri dari pidana mati, pidana penjara, kurungan dan denda, sedangkan pidana tambahan meliputi pencabutan hak-hak tertentu, perampasan barang-barang tertentu dan pengumuman putusan hakim. ${ }^{12}$

Ada sebuah penambahan $1 / 3$ hukuman dalam pasal 7 ayat (1) terkait dengan masalah hukuman yang diberikan kepada pelaku trafficking. Adapun permasalahan yang akan diangkat penulis dalam skripsi ini adalah bagaimana Islam memandang konsep penambahan 1/3 hukuman dalam pasal 7 Undang-Undang No. 21 tahun 2007 tentang pemberantasan tindak pidana perdagangan orang sebagai sanksi hukum bagi pelaku tindak pidana trafficking yang mengakibatkan cacat fisik maupun gangguan mental. Sehingga penulis melakukan penelitian dengan judul "Analisis Fiqh Jinâyah

\footnotetext{
10 Diambil dari putusan Mahkamah Agung RI No. 1699 K/Pid.Sus/2010.

11 Mahrus Ali, Dasar-Dasar Hukum Pidana (Jakarta: Sinar Grafika, 2012), 137.

12 Andi Hamzah, KUHP dan KUHAP(Jakarta: Rineka Cipta, 2006), 6.
} 
Terhadap Penambahan 1/3 Hukuman dalam Pasal 7 Ayat (1) Undang-Undang No. 21 Tahun 2007 tentang Pemberantasan Tindak Pidana Perdagangan Orang."

\section{Tindak Pidana Perdagangan Orang}

Perdagangan orang atau biasa disebut human trafficking ${ }^{13}$ merupakan bentuk perbudakan secara modern, terjadi baik dalam tingkat nasional dan internasional. Wujudnya yang ilegal dan terselubung berupa perdagangan orang melalui bujukan, ancaman, penipuan, dan rayuan untuk direkrut dan dibawa ke daerah lain bahkan ke luar negeri untuk diperjualbelikan dan diperkerjakan diluar kemauannya sebagai pekerja seks, pekerja paksa, atau bentuk perdagangan lainnya. Maraknya isu perdagangan orang ini diawali dengan semakin meningkatnya pencari kerja baik laki-laki maupun perempuan bahkan anak-anak untuk bermigrasi ke luar daerah sampai ke luar negeri guna mencari pekerjaan. Kurangnya pendidikan dan keterbatasan informasi yang dimiliki menyebabkan mereka rentan terjebak dalam perdagangan orang. ${ }^{14}$

Perdagangan orang juga tak bisa dilepaskan dengan masalah hak asasi manusia, karena jelas sekali masalah perdagangan orang ini melanggar hak asasi manusia. Perdagangan orang bertentangan dengan hak asasi manusia karena perdagangan orang melalui cara ancaman, pemaksaan, penculikan, penipuan, kecurangan, kebohongan dan penyalahgunaan kekuasaan serta bertujuan prostitusi, pornografi, kekerasan atau eksploitasi, kerja paksa, perbudakan atau praktik-praktik serupa. Jika salah satu cara tersebut diatas terpenuhi, maka terjadi perdagangan orang yang termasuk sebagai kejahatan yang melanggar hak asasi manusia. ${ }^{15}$

\footnotetext{
${ }^{13}$ Human trafficking adalah istilah asing untuk perdagangan orang yang berarti tindakan perekrutan, pengangkutan, penampungan, pengiriman, pemindahan, atau penerimaan seseorang dengan ancaman kekerasan, penggunaan kekerasan, penculikan, penyekapan, pemalsuan, penipuan, penyalahgunaan kekuasaan atau posisi rentan, penjeratan utang atau memberi bayaran atau manfaat, sehingga memperoleh persetujuan dari orang yang memegang kendali atas orang lain tersebut, baik yang dilakukan di dalam negara maupun antar negara, untuk tujuan eksploitasi atau mengakibatkan orang tereksploitasi. Lihat, Undang-Undang Republik Indonesia Nomor 21 Tahun 2007 Tentang Pemberantasan Tindak Pidana Perdagangan Orang (Surabaya: Kesindo Utama, 2013), 185.

${ }^{14}$ Farhana, Aspek Hukum Perdagangan Orang di Indonesia, 4.

15 Ibid., 11.
} 
Perdagangan orang termasuk extraordinary crimes (kejahatan luar biasa) karena dapat dikategorikan sebagai organized transnational crimes (kejahatan transnasional terorganisasi) yang memerlukan extraordinary measures (cara-cara luar biasa) juga untuk menanggulanginya, dan seringkali cara-cara luar biasa ini menyimpang dari asas-asas hukum pidana umum, baik hukum pidana materiil (KUHP) maupun hukum acara pidana (KUHAP). ${ }^{16}$ Diperlukan instrumen hukum secara khusus untuk melindungi korban perdagangan orang.

\section{Penambahan 1/3 Hukuman dalam Pasal 7 ayat (1) Undang-Undang} No. 21 Tahun 2007

Meskipun sanksi pidana trafficking sangat jelas yaitu penjara 3-15 tahun dan denda Rp. 120 - 600 juta rupiah (Pasal 2-6), namun angka trafficking tidak menunjukkan penurunan. Hal yang demikian ini, sangatlah memprihatinkan. Di dalam pasal 7 ayat (1) menyebutkan bahwa:

Jika tindak pidana sebagaimana dimaksud dalam Pasal 2 ayat (2), Pasal 3, Pasal 4, Pasal 5, dan Pasal 6 mengakibatkan korban menderita luka berat, gangguan jiwa berat, penyakit menular lainnya yang membahayakan jiwanya, kehamilan, atau terganggu atau hilangnya fungsi reproduksinya, maka ancaman pidananya ditambah $1 / 3$ (sepertiga) dari ancaman pidana dalam Pasal 2 ayat (2), Pasal 3, Pasal 4, Pasal 5, danPasal 6.

Ketentuan pidana dalam Undang-Undang Nomor 21 Tahun 2007 tentang Tindak Pidana Perdagangan Orang, bahwa semua unsur tindak pidana perdagangan orang diuraikan dan dikenakan sanksi. Dilihat dari perbuatan perdagangan orang, maka sanksi dapat dibagi menjadi dua bagian yaitu perbuatan yang merupakan tindak pidana perdagangan orang dan perbuatan yang berkaitan dengan tindak pidana perdagangan orang. Untuk lebih jelasnya, terdapat dalam tabel berikut ini. ${ }^{17}$

Di dalam tabel tersebut terlihat jelas perbedaannya antara Pasal 27, yaitu jenis tindak pidananya dengan sanksi yang diberikan. Perhitungan sanksi pidana dalam Pasal 7 ayat (1) adalah 3 tahun (trafficking) $+1 / 3$ hukuman (akibat yang ditimbulkan) $=4$ tahun

\footnotetext{
16 Aziz Syamsuddin, Tindak Pidana Khusus (Jakarta: Sinar Grafika, 2011), 7.

17 Farhana, Aspek Hukum Perdagangan Orang..., 134.
} 
hukuman minimal dan 15 tahun (trafficking) $+1 / 3$ hukuman (akibat yang ditimbulkan) $=20$ tahun hukuman maksimal. Sedangkan dendanya menjadi paling sedikit 160 juta dan paling banyak 800 juta. Namun dalam teori absorbsi dipertajam, penjatuhan pidananya adalah maksimum pidana yang diancamkan ditambah $1 / 3$ hukuman tetapi tidak boleh lebih dari maksimum pidana yang terberat. Contoh kasus di Tulungagung. Di dalam putusan No. 518/ Pid.B/ 2009/ PN. Ta, Pengadilan Negeri Tulungagung telah menjatuhkan hukuman 15 tahun penjara kepada terdakwa karena terdakwa bukan hanya memperdagangkan dan menyetubuhi, tetapi juga melakukan kekerasan fisik yang mengakibatkan luka berat kepada korban. Sehingga terdakwa dikenakan hukuman maksimal yaitu hukuman penjara selama 15 tahun dan denda sebesar Rp. 120.000.000 dengan ketentuan apabila tidak dibayar harus diganti dengan hukuman kurungan selama 12 bulan. ${ }^{18}$

\section{Analisis terhadap Penambahan 1/3 Hukuman dalam Pasal 7 ayat (1) Undang-Undang No. 21 Tahun 2007}

Perdagangan Orang atau biasa disebut human trafficking merupakan bentuk perbudakan secara modern, terjadi baik dalam tingkat nasional dan internasional. Wujudnya yang ilegal dan terselubung berupa perdagangan orang melalui bujukan, ancaman, penipuan, dan rayuan untuk direkrut dan dibawa ke daerah lain bahkan ke luar negeri untuk diperjualbelikan dan diperkerjakan diluar kemauannya sebagai pekerja seks, pekerja paksa, atau bentuk perdagangan lainnya. Maraknya isu perdagangan orang ini diawali dengan semakin meningkatnya pencari kerja baik laki-laki maupun perempuan bahkan anak-anak untuk bermigrasi ke luar daerah sampai ke luar negeri guna mencari pekerjaan. Kurangnya pendidikan dan keterbatasan informasi yang dimiliki menyebabkan mereka rentan terjebak dalam perdagangan orang. ${ }^{19}$

Ada beberapa pasal yang menyebutkan beberapa aspek pidana dalam undang-undang tindak pidana perdagangan orang, yaitu dalam pasal 3, pasal 4, pasal 5, pasal 6 dan pasal 7 (pemberatan). Sedangkan unsur-unsur pidana dalam Pasal 7 ayat (1) UU No. 21 tahun 2007, terdiri dari unsur subjektif dan unsur objektif, yakni sebagai berikut :

\footnotetext{
18 Diambil dari putusan Mahkamah Agung RI No. 1699 K/Pid.Sus/2010.

${ }^{19}$ Farhana, Aspek Hukum Perdagangan Orang di Indonesia (Jakarta: Sinar Grafika, 2012), 4.
} 
a. Unsur subjektif :

- Orang yang mampu (bisa instansi maupun perorangan) yang melakukan kejahatan perdagangan orang.

- Adanya kesalahan perbuatan, artinya perbuatan trafficking telah melanggar aturan Undang-Undang yaitu memindahkan dan mengangkat seseorang atau anak untuk dieksploitasi.

b. Unsur objektif :

- Adanya perbuatan orang/instansi.

- Akibat dari tindak pidana perdagangan orang yaitu cacat fisik maupun mental

Dari mulai pasal 2 sampai pasal 7 cara melakukan delik yang dilakukan berbeda-beda akan tetapi hukuman yang diberikan sama kecuali pasal 7 ada pemberatan sanksi.

Indonesia sampai sekarang ini belum memiliki sistem pemidanaan yang bersifat nasional yang di dalamnya mencakup pola pemidanaan dan pedoman pemidanaan, yaitu acuan atau pedoman bagi pembuat undangundang dalam membuat atau menyusun peraturan perundang-undangan yang mengandung sanksi pidana. Istilah pola pemidanaan ini sering juga disebut "pedoman legislatif" atau "pedoman formulatif". Sedangkan pedoman pemidanan adalah pedoman penjatuhan atau penerapan pidana untuk hakim ("pedoman yudikatif" atau "pedoman aplikatif"). Dilihat dari fungsi keberadaannya, maka pola pemidanaan ini seharusnya ada lebih dahulu sebelum perundang-undangan pidana dibuat, bahkan sebelum KUHP nasional dibuat.

Menurut Jonkers dasar pemberatan atau penambahan pidana adalah sebagai berikut: ${ }^{20}$

a. Kedudukan sebagai pegawai negeri

b. Recidive (pengulangan delik)

c. Samenloop atau Concursus (gabungan atau perbarengan dua atau lebih delik)

Jika pengadilan ingin menjatuhkan pidana maksimum, maka pidana tertinggi yang dapat dijatuhkan ialah maksimum pidana delik itu ditambah dengan sepertiganya. Pemberatan sanksi dengan penambahan $1 / 3$ hukuman dalam Pasal 7 ayat (1) Undang-Undang No. 21 Tahun 2007 dapat terjadi jika obyeknya mengalami luka berat, gangguan jiwa berat, penyakit menular lainnya yang membahayakan jiwanya,

\footnotetext{
${ }^{20}$ Zainal Abidin Farid, Hukum Pidana I Jakarta: Sinar Grafika, 1995), 427.
} 
kehamilan, atau terganggu atau hilangnya fungsi reproduksinya. Penambahan 1/3 hukuman terjadi karena dalam Pasal 7 ayat (1) melakukan perbuatan memperjual-belikan orang (trafficking) dan juga melakukan penganiayaan secara sengaja terhadap korban.

Setelah disahkannya Undang-Undang Nomor 21 Tahun 2007 tentang Pemberantasan Tindak Pidana Perdagangan Orang, pada 19 April 2007 yang merupakan peraturan yang khusus yang mengatur tentang tindak pidana perdagangan orang, sehingga dapat menjadi sarana bagi penegakan hukum, khususnya terhadap penanganan perdagangan orang. Adapun perlindungan korban belum mendapat perhatian, hal ini terlihat dari masih sedikitnya aturan dalam peraturan perundangundangan mengenai hak-hak korban. Keberpihakan hukum terhadap korban yang terkesan timpang jika dibandingkan dengan tersangka (terdakwa) dibandingkan kepada korban. Dalam beberapa kasus kejahatan, seringkali wujud perlindungan hukum yang diberikan kepada korban termasuk korban perdagangan orang hanya terbatas pada aspek materiil saja, yaitu diberi hak untuk menuntut ganti kerugian. Harapannya setelah ganti kerugian diberikan penderitaan yang dihadapi korban akan selesai. Padahal akibat yang diderita korban sangat kompleks, tidak hanya kerugian materiil saja tetapi secara fisik dan psikis. ${ }^{21}$

Meskipun sanksi pidana trafficking sangat jelas yaitu penjara 3-15 tahun dan denda Rp. 120 - 600 juta rupiah (Pasal 2-6), namun angka trafficking tidak menunjukkan penurunan. Hal yang demikian ini, sangatlah memprihatinkan. Di dalam pasal 7 ayat (1) menyebutkan bahwa:

"Jika tindak pidana sebagaimana dimaksud dalam Pasal 2 ayat (2),

Pasal 3, Pasal 4, Pasal 5, dan Pasal 6 mengakibatkan korban menderita luka berat, gangguan jiwa berat, penyakit menular lainnya yang membahayakan jiwanya (HIV/AIDS), kehamilan, atau terganggu atau hilangnya fungsi reproduksinya (selaput dara tidak utuh atau rusak), maka ancaman pidananya ditambah $1 / 3$ (sepertiga) dari ancaman pidana dalam Pasal 2 ayat (2), Pasal 3, Pasal 4, Pasal 5, danPasal 6."

Penambahan 1/3 hukuman terjadi dikarenakan adanya akibat yang ditimbulkan dari perbuatan pidana tersebut. Dalam Pasal 7 ayat (1)

${ }^{21}$ Farhana, Aspek Hukum Perdagangan Orang..., 19-20. 
selain melakukan trafficking, pelaku juga memenuhi unsur penganiayaan yang disengaja. Karena mengakibatkan korban mengalami luka berat (perlukaan), gangguan jiwa berat, penyakit menular lainnya yang membahayakan jiwanya, kehamilan, atau terganggu atau hilangnya fungsi reproduksinya. Sehingga terdapat gabungan atau perbarengan hukuman tindak pidana.

Menurut analisis penulis, penambahan 1/3 hukuman termasuk concursus realis yang sistem hukumannya disebut sistem absorbsi stelsel yang dipertajam. Concursus realis adalah gabungan perbuatan yang terjadi jika seseorang yang melakukan dua atau lebih kejahatan sehingga secara hukum dipandang telah melanggar dua atau lebih aturan pidana. Dengan kata lain, seseorang melakukan beberapa perbuatan yang tidak ada hubungannya satu sama lain dan masing-masing perbuatan itu merupakan tindak pidana yang berdiri sendiri. Bentuk gabungan perbuatan ini memiliki beberapa sistem hukuman. Sistem hukuman yang termasuk dalam Pasal 7 ayat (1) adalah sistem absorbsi stelsel yang dipertajam. Sistem absorbsi stelsel yang dipertajam (verscherpte absorbi stelsel) adalah gabungan perbuatan yang terdiri dari beberapa kejahatan yang masing-masing diancam dengan pidana pokok yang sejenis. Dalam penjatuhan pidananya, hanya menjatuhkan satu pidana saja dan maksimum pidana yang dijatuhkan itu adalah jumlah maksimum pidana yang diancamkan terhadap tindak pidana itu, tetapi tidak boleh lebih dari maksimum pidana yang terberat ditambah sepertiganya. ${ }^{22}$ Sistem ini diatur dalam Pasal 65 KUHP. Misalnya, kasus di Tulungagung. Di dalam putusan No. 518/ Pid.B/ 2009/ PN. Ta, Pengadilan Negeri Tulungagung telah menjatuhkan hukuman 15 tahun penjara kepada terdakwa karena terdakwa bukan hanya memperdagangkan dan menyetubuhi, tetapi juga melakukan kekerasan fisik kepada korban. Sehingga terdakwa dikenakan hukuman penjara selama 15 tahun dan denda sebesar Rp. 120.000.000 dengan ketentuan apabila tidak dibayar harus diganti dengan hukuman kurungan selama 12 bulan. Di dalam kasus tersebut terlihat bahwa hukuman yang dijatuhkan adalah 15 tahun penjara. Sedangkan dalam Undang-Undang trafficking batas maksimum hukuman penjara adalah 15 tahun. Sehingga walaupun terdapat unsur penganiayaan, penambahan 1/3 hukuman tidak diberlakukan karena hukuman utamanya sudah mencapai batas maksimum.

22 Mahrus Ali, Dasar-Dasar Hukum Pidana (Jakarta: Sinar Grafika, 2012), 137. 
Berkaitan dengan sistem absorbsi stelsel yang dipertajam, terdapat teori gabungan perbuatan dalam KUHP yang termasuk dalam sistem ini yang disebut dengan teori penyerapan keras. Teori ini mengenai gabungan perbuatan nyata (concursus realis) yang diancam hukuman pokok yang semacam. Sehingga salah satu hukuman saja yang dijatuhkan dan hukuman tersebut diberatkan dengan ditambah sepertiga dari maksimum hukuman yang seberat-beratnya.

Ketentuan pidana dalam Undang-Undang Nomor 21 Tahun 2007 tentang Tindak Pidana Perdagangan Orang, bahwa semua unsur tindak pidana perdagangan orang diuraikan dan dikenakan sanksi. Dilihat dari perbuatan perdagangan orang, maka sanksi dapat dibagi menjadi dua bagian yaitu perbuatan yang merupakan tindak pidana perdagangan orang dan perbuatan yang berkaitan dengan tindak pidana perdagangan orang. Untuk lebih jelasnya, terdapat dalam tabel berikut ini. ${ }^{23}$

Dengan memperhatikan tabel tersebut, penulis dapat menyimpulkan bahwa penetapan pidana penambahan $1 / 3$ hukuman dalam Pasal 7 ayat (1) dikarenakan adanya perbuatan lain yang berkaitan dengan perbuatan tindak pidana perdagangan orang yaitu penganiayaan yang mengakibatkan korban menderita luka berat, gangguan jiwa berat, penyakit menular lainnya yang membahayakan jiwanya (HIV/AIDS), kehamilan, atau terganggu atau hilangnya fungsi reproduksi (selaput dara tidak utuh atau rusak). Sehingga di dalam Pasal 7 ayat (1) menyebutkan bahwa jika tindak pidana trafficking tersebut mengakibatkan luka berat dan lain-lainnya, maka ancaman hukumannya ditambah $1 / 3$ dari ancaman hukuman sebelumnya. Hukuman sebelumnya yaitu pidana penjara paling singkat 3 tahun dan paling lama 15 tahun dengan pidana denda paling sedikit Rp. 120.000.000,00 dan paling banyak Rp. 600.000.000,00. Dapat ditarik kesimpulan bahwa sanksi pidana dalam Pasal 7 ayat (1) yang semula hukumannya minimal 3 tahun dan maksimal 15 tahun kemudian terjadi penambahan 1/3 hukuman, maka sanksi pidana penjaranya menjadi paling singkat 4 tahun dan paling lama 20 tahun dengan disertai pidana denda paling sedikit Rp. 160.000.000,00 dan paling banyak Rp. 800.000.000,00.

${ }^{23}$ Farhana, Aspek Hukum Perdagangan Orang..., 134. 


\section{Analisis Hukum Pidana Islam terhadap Penambahan 1/3 Hukuman bagi pelaku tindak pidana Perdagangan Orang}

Allah yang maha bijaksana tidak berlebihan dalam segala sesuatu dengan sebaik-baiknya. Adanya hudûd, qishâsh-diyat, kafarat dan ta'zîr adalah untuk menjaga kemaslahatan manusia di dunia. Dalam menciptakan hukum serapi-rapinya yang memberikan jaminan kebahagiaan bagi manusia dengan penuh kemaslahatan.

Qishâsh-diyat merupakan sanksi yang diperuntukkan bagi pelaku pembunuhan dan penganiayaan. Hukuman qishâsh berlaku untuk jarîmah pembunuhan sengaja dan penganiayaan sengaja. Sedangkan diyat merupakan hukuman pokok untuk tindak pidana pembunuhan dan penganiayaan semi sengaja dan tidak sengaja. Ketentuan ini didasarkan kepada firman Allah dalam Surat Al-Nisa' ayat 92 yang berbunyi:

Dan tidak layak bagi seorang mukmin membunuh seorang mukmin (yang lain), kecuali karena tersalah (tidak sengaja), dan Barangsiapa membunuh seorang mukmin karena tersalah (hendaklah) ia memerdekakan seorang hamba sahaya yang beriman serta membayar diyat yang diserahkan kepada keluarganya (si terbunuh itu), kecuali jika mereka (keluarga terbunuh) bersedekah. Jika ia (si terbunuh) dari kaum (kafir) yang ada perjanjian (damai) antara mereka dengan kamu, maka (hendaklah si pembunuh) membayar diyat yang diserahkan kepada keluarganya (si terbunuh) serta memerdekakan hamba sahaya yang beriman. Barangsiapa yang tidak memperolehnya, maka hendaklah ia (si pembunuh) berpuasa dua bulan berturutturut untuk penerimaan taubat dari pada Allah. Dan adalah Allah Maha mengetahui lagi Maha Bijaksana. ${ }^{24}$

Dalam hal ini perlu adanya hukuman bagi pelaku trafficking yang mengakibatkan luka berat. Hukuman dalam bahasa Arab disebut 'uqûbâh. Lafaz' uqûbâh menurut bahasa berasal dari kata: (عَََ )yang artinya mengiringnya dan datang di belakangnya. Sehingga dapat dipahami bahwa sesuatu disebut hukuman karena ia mengiringi perbuatan dan dilaksanakan sesudah perbuatan itu dilakukan. Sedangkan menurut istilah hukuman adalah salah satu tindakan yang diberikan oleh syara' sebagai pembalasan atas perbuatan yang melanggar ketentuan

\footnotetext{
${ }^{24}$ Departemen Agama RI, Al-Qur'an dan..., 135.
} 
syara', dengan tujuan untuk memelihara ketertiban dan kepentingan masyarakat, sekaligus juga untuk melindungi kepentingan individu. ${ }^{25}$

Dalam hukum pidana Islam, ada beberapa unsur atau perbuatan itu disebut sebagai jinayah yaitu diantaranya adalah: Pertama, adanya nash yang melarang perbuatan-perbuatan tertentu yang disertai ancaman hukuman atas perbuatan-perbuatan pidana. Unsur ini dikenal dengan unsur formal (al-rukn al-syar'i). Kedua, adanya unsur perbuatan yang membentuk jinayah,baik berupa meninggalkan perbuatan yang diharuskan atau melakukan perbuatan yang dilarang. Unsur ini dikenal dengan unsur material (al-ruknal-madi). Ketiga, pelaku kejahatan adalah orang yang dapat menerima panggilan (khitbah) atau dapat memahami pembebanan (taklif), artinya pelaku kejahatan tadi adalah mukallaf sehingga mereka dapat dituntut atas kejahatan yang mereka lakukan. Unsur ini dikenal dengan istilah unsur moral (al-rukn al-adabi).

Bagian terpenting dalam sistem pemidanaan adalah menetapkan sanksi. Keberadaannya akan memberikan arah dan pertimbangan mengenai apa yang seharusnya dijadikan sanksi dalam suatu tindak pidana untuk menegakkan berlakunya norma. Di sisi lain, pemidanaan itu sendiri merupakan proses paling kompleks dalam sistem peradilan pidana karena melibatkan banyak orang dan institusi yang berbeda. Penentuan jenis ancaman pidana, penjatuhan dan pelaksanaan pidana berhubungan erat dengan tujuan pemidanaan. Permasalahannya, apakah jenis-jenis pidana tersebut sudah menggambarkan tujuan yang hendak dicapai dalam pemidanaan.

Adanya sanksi berupa pidana ditentukan oleh ada dan tidak adanya perbuatan yang dikehendaki (dilarang). Suatu perbuatan yang tidak dikehendaki (dilarang) oleh masyarakat dapat diwujudkan dalam bentuk peraturan. Perbuatan yang tidak dikehendaki adalah perbuatan negatif. Artinya, perbuatan yang tidak dikehendaki secara tegas dinyatakan dilarang.

Ketika melihat kasus trafficking yang terjadi, para trafficker mulai dari perekrutan, pengangkutan, pemindahan, penyembunyian, atau penerimaan seseorang melalui penggunaan ancaman atau tekanan, atau bentuk-bentuk lain dari kekerasan penculikan, kecurangan, penipuan, penyalahgunaan wewenang atau posisi rentan atau memberikan atau

${ }^{25}$ Ahmad Wardi Muslich, Pengantar dan Asas Hukum Pidana Islam: Fikih Jinayah (Jakarta: Sinar Grafika, 2004), 137. 
menerima pembayaran sehingga mendapatkan persetujuan dari seseorang yang memegang kendali atas orang lain tersebut, untuk tujuan eksploitasi mencakup paling tidak, eksploitasi pelacuran oleh orang lain, atau bentuk lain eksploitasi seksual, kerja atau pelayanan paksa, perbudakan, atau praktek-praktek yang hampir sama dengan perbudakan, penghambaan atau pengambilan organ tubuh, harus diberi sanksi yang tegas.

Dalam Pasal 7 ayat (1) UU No. 21 tahun 2007 telah memberikan sanksi yang tegas bagi pelaku trafficking. Indikasi yang dapat dilihat adalah adanya pemberatan sanksi pidana yaitu penambahan $1 / 3$ hukuman dari ancaman hukuman sebelumnya.

Di dalam fiqh jinayah, hukuman dapat dibagi menjadi beberapa golongan menurut segi tinjauannya yaitu berdasarkan pertalian satu hukuman dengan lainnya yang meliputi hukuman pokok (al-'uqûbâh alashliyyah), hukuman pengganti (al-'uqûbâh al-badaliyyah), hukuman tambahan (al-'uqûbâh al-tab'iyyah) dan hukuman pelengkap (al-'uqûbâh al-takmîliyyah).

Berdasarkan analisis penulis terhadap penambahan 1/3 hukuman dalam Pasal 7 ayat (1), ternyata ditemukan mengandung dua unsur hukuman yaitu termasuk dalam al-'uqûbâh al-badaliyyah dan al-'uqûbâh al-takmîliyyah. Termasuk al-'uqûbâh al-badaliyyah karena di dalam Pasal 7 ayat (1) terdapat unsur jarîmah penganiayaan yang disengaja sehingga harus menggunakan hukuman qishâsh(balasan setimpal). Namun qishâsh sebagai hukuman pokok (al-'uqûbâh al-ashliyyah) sulit diterapkan dalam trafficking sehingga harus menggunakan diyat sebagai hukuman pengganti (al-'uqûbâh al-badaliyyah). Hukuman qishâshterhalang karena hukumannya tidak dapat dilaksanakan terhadap pelaku tindak pidana perdagangan orang. Hal ini logis ketika korban mengidap penyakit yang menular, gangguan jiwa berat, hamil dan rusaknya alat vitalnya maka tidak mungkin dibalas setimpal. Namun jika mengakibatkan luka berat (perlukaan) dan hilangnya reproduksimaka dapat dilaksanakan hukuman qishâsh.

Pemotongan, menghilangkan fungsi, membuat cacat atau melukai anggota badan dikenakan diyat sebagai berikut : ${ }^{26}$

- Diyat 100 ekor unta (seharga 1000 dinar) yaitu bagi anggota badan yang berpasangan.

\footnotetext{
${ }^{26}$ Rahmat Hakim, Hukum Pidana Islam: Fiqh Jinayah (Bandung: Pustaka Setia, 2010), 131.
} 
- Diyat 50 ekor unta yaitu bagi anggota badan yang berpasangan jika salah satunya terpotong.

- Diyat 33 ekor unta yaitu bagi luka kepala sampai otak,luka badan sampai perut.

- Diyat 15 ekor unta (seharga 150 dinar), jika melukai kulit diatas tulang.

- Diyat 10 ekor unta (seharga 100 dinar), jika melukai sampai mematahkan tulang.

- Diyat 5 ekor unta (seharga 50 dinar), jika melukai mata atau kepala sampai menampakkan tulang.

Diyat yang digunakan dalam jarîmah ini adalah diyah kâmilah (diyat lengkap), karena mengakibatkan perlukaan yang berat dan sulit untuk disembuhkan. Ad-diyatul kâmilah adalah seratus ekor unta atau seharga uang 1000 dinar. $^{27} \quad$ Pelakunya patut di hukum ad-diyatul kâmilah oleh hakim atau penguasa. Ini didasarkan atas hukuman yang memang dapat dilaksanakan terhadap pelaku. Di Indonesia juga terdapat hukuman Diyat(denda), seperti dalam Pasal 7 ayat (1) yaitupaling sedikit Rp. 160.000.000,00 dan paling banyak Rp. 800.000.000,00. Harga 1 ekor unta adalah Rp. 50.000.000,00, maka diyatseratus ekor unta senilai dengan Rp. 5.000.000.000,00 (lima miliar rupiah). Denda dalam Pasal 7 ayat (1) Undang-Undang No. 21 Tahun 2007 tidak sesuai dengan diyat (denda) yang senilai dengan 100 ekor unta. Hal ini disebabkan karena nominal denda yang terdapat dalam Pasal 7 ayat (1), yaituantara Rp. 160.000.000,00 - Rp. 800.000.000,00 lebih sedikit dibandingkan dengan nominal seratus ekor unta seharga Rp. 5.000.000.000,00 (lima miliar rupiah).

Di samping terhalang oleh beberapa sebab, hukuman qishâsh juga dapat gugur karena beberapa sebab. Diantaranya yaitu:

1. Tidak adanya tempat (obyek qishâsh).

2. Adanya pengampunan dari keluarga korban.

3. Adanya perdamaian.

Sedangkan termasuk al-'uqûbâh al-takmîliyyah dalam penambahan $1 / 3$ hukuman karena memenuhi unsur penambahan hukuman yang mengikuti hukuman pokok. Hukuman pokok bagi pelaku trafficking adalah pidana penjara minimal tiga tahun dan maksimal lima belas tahun. Kemudian pidana denda paling sedikit Rp.

${ }^{27}$ Abdul Qadir Audah, Ensiklopedi Hukum Pidana Islam, Jilid 3 (Jakarta: Kharisma Ilmu, 2007), 73. 
120.000.000,00 (seratus dua puluh juta rupiah) dan paling banyak Rp. $600.000 .000,00$ (enam ratus juta rupiah). Ketika terjadi penambahan hukuman yang mengikuti dari hukuman pokok, maka hukuman tersebut dapat dikatakan sebagai hukuman pelengkap (al-'uqûbâh al-takmîliyyah). Karena hukuman tersebut merupakan penyempurna dari hukuman sebelumnya. Sehingga penulis menarik kesimpulan dari teori tersebut bahwa penambahan 1/3 hukuman dalam Pasal 7 ayat (1) merupakan teori al-'uqûbâh al-badaliyyah al-takmîliyyah (hukuman pengganti dan pelengkap).

\section{Simpulan}

Penetapan pidana dalam Pasal 7 ayat (1) yang semula hukumannya minimal 3 tahun dan maksimal 15 tahun kemudian terjadi penambahan $1 / 3$ hukuman, maka sanksi pidana penjaranya menjadi paling singkat 4 tahun dan paling lama 20 tahun dengan disertai pidana denda paling sedikit Rp. 160.000.000,00 dan paling banyak Rp. $800.000 .000,00$.

Penambahan 1/3 hukuman dalam Pasal 7 ayat (1), ternyata ditemukan mengandung dua unsur hukuman yaitu termasuk dalam al'uqûbâh al-badaliyyah dan al-'uqûbâh al-takmîliyyah. Hukuman al'uqûbâh al-badaliyyah terjadi di dalam Pasal 7 ayat (1) yang mengandung unsur jarîmah penganiayaan yang disengaja sehingga harus menggunakan hukuman qishâsh(balasan setimpal). Namun qishâsh sebagai hukuman pokok (al-'uqûbâh al-ashliyyah) sulit diterapkan dalam trafficking sehingga harus menggunakan diyat sebagai hukuman pengganti (al'uqûbâh al-badaliyyah). Diyat yang digunakan adalah ad-diyatul kâmilah (diyat lengkap) yaitu 100 ekor unta atau senilai dengan Rp. 5.000.000.000,00 (lima miliar rupiah) untuk perlukaan yang berat. Sedangkan termasuk al-'uqûbâh al-takmîliyyah dalam penambahan $1 / 3$ hukuman karena memenuhi unsur penambahan hukuman yang mengikuti hukuman pokok. Hukuman pokok bagi pelaku trafficking adalah pidana penjara minimal tiga tahun dan maksimal lima belas tahun. Ketika terjadi penambahan hukuman yang mengikuti dari hukuman pokok, maka hukuman tersebut dapat dikatakan sebagai hukuman pelengkap (al-'uqûbâh al-takmîliyyah). Karena hukuman tersebut merupakan penyempurna dari hukuman sebelumnya. Sehingga penambahan 1/3 hukuman dalam Pasal 7 ayat (1) merupakan teori al- 
'uqûbâh al-badaliyyah al-takmîliyyah (hukuman pengganti dan pelengkap).

\section{Daftar Rujukan}

Ali, Mahrus. Dasar-Dasar Hukum Pidana. Jakarta: Sinar Grafika, 2012.

Ali, Zainuddin. Hukum Pidana Islam. Jakarta: Sinar Grafika, 2009.

Audah, Abd. al-Qadir. Al-Tasyri' Al-Jina’iy Al-Islamiy, Juz 1. Kairo: Maktabah Dar al-Turas, 2005.

-.-.---, Ensiklopedi Hukum Pidana Islam. Terjemahan Ahsin Sakho Muhammad. Jakarta: Kharisma Ilmu, 2007.

Bisri, Adib. Tarjamah Al-Fara'idul Bahiyyah. Kudus: Menara Kudus, 1977.

Djazuli, A. Fiqh Jinayah. Jakarta: Raja Grafindo Persada, 2000.

Farhana. Aspek Hukum Perdagangan Orang di Indonesia. Jakarta: Sinar Grafika, 2012.

Farid, Abidin Zainal. Hukum Pidana 1. Jakarta: Sinar Grafika, 1995.

Hakim, Rahmat. Hukum Pidana Islam. Bandung: Pustaka Setia, 2000.

Hamzah, Andi. Asas-Asas Hukum Pidana. Jakarta: Rineka Cipta, 1994. KUHP dan KUHAP. Jakarta: Rineka Cipta, 2006.

Hanafi, Ahmad. Asas-Asas Hukum Pidana Islam. Jakarta: Bulan Bintang, 1990.

Haq, Abdul. Formulasi Nalar Fiqh. Surabaya: Khalista, 2006.

Marpaung, Leden. Asas-Teori-Praktik Hukum Pidana. Jakarta: Sinar Grafika, 2008.

Muslich Wardi Ahmad, Pengantar dan Asas Hukum Pidana Islam: Fikih Jinayah. Jakarta: Sinar Grafika, 2006.

Prodjodikoro, Wirjono. Asas-Asas Hukum Pidana di Indonesia. Bandung: Eresco, 1989.

Sugiyono. Metode Penelitian Kuantitatif Kualitatif dan R\&D. Bandung: Alfabeta, 2008.

Syamsuddin, Aziz. Tindak Pidana Khusus. Jakarta: Sinar Grafika, 2011.

Utrecht, E. Hukum Pidana II. Surabaya: Pustaka Tinta Mas, 1965.

Departemen Agama RI. Al-Qur'an dan Terjemahannya. Jakarta: Yayasan Penyelenggara Penterjemahan, 1971.

Farida, Nova. "Perdagangan Manusia Dalam Hukum HAM Dan Perspektif Islam”, dalam 
http://novafarid.blogspot.com/2012/12/perdagangan-manusia-

dalam-hukum-ham-dan.html, diakses pada 24 Desember 2012.

Putusan Mahkamah Agung RI No. 1699 K/Pid.Sus/2010.

Software Kitab Hadis 9 Imam, Kitab Sahih Imam Al-Bukhâri, CD Hadis.

Tim Penyusun Kamus Pusat Bahasa Departemen Pendidikan Nasional. Kamus Besar Bahasa Indonesia. Jakarta: Balai Pustaka, 2005.

Undang-Undang RI No. 21 Tahun 2007 tentang Pemberantasan Tindak Pidana Perdagangan Orang. Surabaya: Kesindo Utama, 2013. 